\title{
IMPLEMENTASI PERHITUNGAN BIAYA PRODUKSI USAHA TANI JAGUNG (STUDI PENELITIAN DI DUSUN TUMBA, DESA PONGONGAILA, KECAMATAN PULUBALA)
}

\author{
Mei K. Abdullah \\ IAIN Sultan Anai Gorontalo \\ Email: meiabdullah@iaingorontalo.ac.id
}

\begin{abstract}
Abstrak
Bertani jagung adalah profesi utama penduduk Dusun Tumba, Desa Pongongaila, Kecamatan Pulubala, Kabupaten Gorontalo. Usaha ini dapat meningkatkan kesejahteraan masyarakat yang berada di wilayah ini. Hasil penelitian menunjukkan bahwa dengan melakukan perhitungan biaya produksi secara baik dan berkesinambungan, kita dapat mengetahui total biaya produksi (Biaya Bahan Baku, Biaya Tenaga Kerja, dan Biaya Overhead Pabrik) di setiap musimnya, biaya produksi perunit dan keuntungan yang diperoleh setiap musimnya.
\end{abstract}

Keyword: Bertani, Biaya Produksi, Keuntungan

\section{PENDAHULUAN}

Indonesia dikenal sebagai Negara Agraris karena sebagian besar penduduk Indonesia bermata pencaharian sebagai petani. Jika kita membahas perekonomian di sector agraris, maka yang menjadi ujung tombak perekonomian di sector ini adalah petani. Mohammad Abduh (2020) dalam diskusi online tentang The Role Of Islamic Social Finance In Achieving SDG No. 2 And Fighting Pandemic menyatakan bahwa petani harusnya lebih sejahtera ketika menjalankan usaha di bidang sektor pertanian, karena mereka yang akan mendukung kebutuhan konsumsi sektor lainnya (Kesehatan: Dalam Pemenuhan Gizi Ibu dan Anak). Di Negara Brunei Darussalam misalnya, pemerintah justru mengajak masyarakatnya menjadi petani dan akan diberikan modal dalam usaha pertaniannya.

Bertani merupakan usaha yang paling menjanjikan di wilayah Dusun Tumba, Desa Pongongaila, Kecamatan Pulubala, Kabupaten Gorontalo. Hal ini disebabkan oleh mudahnya akses pasar ketika masyarakat memanen hasil jagung. Di kecamatan Pulubala sendiri sudah ada 4 gudang jagung dari perusahaan yang berbeda di antaranya adalah PT Seger Pangan Sejahtera, PT Segar Pangan Abadi, PT Chaeron Phokpand. Adanya gudang jagung sangat memudahkan petani selain karena kemudahan pasar, mereka juga tidak terjebak pada tengkulak dan permainan harga jagung yang dimainkan tengkulak. Sebagian besar penduduk Dusun Tumba berprofesi sebagai petani sebagaimana data berikut ini:

Tabel 1: Data Pekerjaan Masyarakat Dusun Tumba

\begin{tabular}{|c|l|c|c|c|c|}
\hline No & Pekerjaan & L & P & L (\%) & P (\%) \\
\hline 1 & Petani & 201 & 0 & $64 \%$ & $0 \%$ \\
\hline 2 & Buruh Tani & 2 & 0 & $1 \%$ & $0 \%$ \\
\hline 3 & Buruh Pabrik & 0 & 1 & $0 \%$ & $4 \%$ \\
\hline 4 & PNS & 0 & 9 & $0 \%$ & $32 \%$ \\
\hline
\end{tabular}




\begin{tabular}{|c|l|c|c|c|c|}
5 & Pegawai Swasta & 59 & 13 & $19 \%$ & $46 \%$ \\
\hline 6 & Wiraswasta & 50 & 0 & $16 \%$ & $0 \%$ \\
\hline 7 & TNI & 2 & 0 & $1 \%$ & $0 \%$ \\
\hline 8 & Polri & 1 & 1 & $0 \%$ & $4 \%$ \\
\hline 9 & Disabilitas & 1 & 4 & $0 \%$ & $14 \%$ \\
\hline & & 316 & 28 & & \\
\hline
\end{tabular}

Sumber: Data Kepala Dusun Tumba dan Pengolahan

Berdasarkan data di atas bahwa ada 8 jenis pekerjaan yang dilakoni oleh penduduk Dusun Tumba, Desa Pongongaila dengan presentase jumlah tertinggi adalah petani sebanyak 64\%, Pegawai Swasta sebanyak 19\%, wiraswasta sebanyak 16\%, TNI dan Buruh tani masing-masing $1 \%$ untuk penduduk laki-lakinya. Data ini belum mencerminkan jumlah sepenuhnya karena ada penduduk perempuan sebagai anggota keluarga dihitung berprofesi sebagai Ibu Rumah Tangga (IRT), namun berprofesi sebagai petani untuk membantu suaminya, atau bahkan profesi bertani ini bias dihitung $50 \%$ oleh Istri dan 50\% oleh suami untuk beberapa rumah tangga tertentu (Abdullah,2020).

Usaha pertanian sebagai salah satu sector usaha penting dan menguntungkan di wilayah ini. Menurut Warren (2016) secara umum usaha atau perusahaan adalah suatu organisasi dengan sumber daya (input), seperti bahan baku dan tenaga kerja, digabung dan diproses untuk menyediakan barang atau jasa untuk pelanggan. Adapun tujuan dari kebanyakan jenis usaha adalah memaksimalkan keuntungan. Yang dimaksud dengan keuntungan adalah selisih antara uang (biaya) yang dikeluarkan untuk menghasilkan barang dan jasa. Adapun Usahatani menurut Djamali (2000), adalah kesatuan organisasi antara faktor produksi berupa lahan, tenaga kerja, modal dan manajemen yang bertujuan untuk memproduksi komoditas pertanian.

Usaha pertanian sebagai salah satu sektor usaha penting dan menghasilkan keuntungan harusnya sudah dapat dikelola dengan baik, termasuk didalamnya adalah masalah pencatatan keuangan. Petani tiak dapat menentukan apakah di tahun (musim) ini mendapatkan keuntungan atau mengalami break event point tanpa adanya catatancatatan pengeluaran produksi.

Berdasarkan pengamatan peneliti, petani di Dusun Tumba ini, sedikit sekali yang melakukakan pencatatan pengeluaran biaya produksi secara baik, meskipun sudah ada catatan-catatan kecil misalnya untuk biaya tenaga kerja penanaman, atau kegiatan-kegiatan pada saat pemanena yang menyangkut hak-hak pekerja, misalnya si A dapat mengupas jagung berapa karung, si B berapa karung sehingga dapat di totalkan berapa biaya yang dapat dibayarkan. Menurut peneliti, catatan biaya produksi itu hendaklah dimulai ketika proses penanaman hingga menjadi biji jagung siap jual sehinga dari penghasilan yang kita dapatkan, kita dapat menentukan berapa biaya produksinya dan muaranya kita dapat menghitung keuntungan secara tepat.

\section{METODE PENELITIAN}

Metode yang digunakan dalam penelitian ini adalah metode deskriptif kualitatif. Metode deskriptif adalah suatu metode dalam meneliti status sekelompok manusia, suatu objek, suatu set kondisi, suatu sistem pemikiran, ataupun suatu kelas peristiwa pada masa sekarang (Nazir, 2014). Tujuan dari penelitian deskriptif adalah untuk 
membuat deskripsi, gambaran, atau lukisan secara sistematis, faktual dan akurat mengenai fakta-fakta, sifat-sifat serta hubungan antara fenomena yang diselidiki. Penelitian dilakukan dengan melakukan wawancara kepada petani tentang jumlah biaya yang biasanya mereka keluarkan dalam satu periode tanam. Data-data ini kemudian dikumpulkan dan di analisis sesuai dengan teori-teori akuntansi biaya yang ada.

\section{HASIL PENELITIAN DAN PEMBAHASAN}

Usaha tani jagung, dapat dikategorikan sebagai usaha yang berproduksi berdasarkan proses karena memproduksi produk yang hampir sama atau sejenis secara besar-besaran. Beberapa karakteristik perusahaan yang menggunakan metode proses (Sujarweni,2015) adalah:

1. Proses produksi berlangsung secara terus-menerus

2. Produk yang dihasilkan standar dan diproduksi secara masal dan regular

3. Dalam metode harga pokok proses lebih menekankan pada penggunaan laporan harga pokok produksi perdepartemen

4. Harga pokok produk dihitung pada akhir periode tertentu

\section{Biaya Bahan Baku}

Biaya bahan baku atau bahan langsung merupakan bahan yang dapat ditelusuri langsung pada barang atau jasa yang langsung dapat dibebankan pada produk. Bahan langsung disebut juga sebagai utama. Dalam usaha tani Jagung, yang menjadi bahan baku atau bahan utamanya adalah benih jagung. Benih jagung dalam penelitian ini dijadikan sebagai dasar perhitungan biaya produksi, bukan luas tanah (area pertanian). Adapun benih jagung yang digunakan sebagai dasar perhitungan dalam penelitian ini adalah sebanyak 2 Sak pabrik atau sebanyak $10 \mathrm{Kg}$. Harga beninh jagung di pasar juga bervariasi dalam rentang Rp 400.000,- Hingga Rp 600.000 per $5 \mathrm{Kg}$.

Tabel 2: Perhitungan Biaya Bahan Baku

\begin{tabular}{|c|l|c|c|c|c|}
\hline No & \multicolumn{1}{|c|}{ Jenis Biaya } & Unit & Satuan & Harga (Rp) & Jumlah (Rp) \\
\hline 1 & $\begin{array}{l}\text { Biaya Bahan Baku } \\
\text { (Benih Jagung) }\end{array}$ & 2 & $\mathrm{Kg}$ & 400.000 & 800.000 \\
\hline
\end{tabular}

Sumber: Data Olahan

\section{Biaya Tenaga Kerja}

Biaya tenaga kerja langsung merupakan biaya tenaga kerja yang terlibat langsung dengan pembuatan produk, atau karyawan (tenaga kerja) yang mengubah bahan baku menjadi sebuah produk. Tenaga kerja dibidang pertanian terdiri atas beberapa jenis sebagaiman dijelaskan oleh Abdullah (2019) (1) Penyemprotan Pestisida, (2) Proses penggemburan, (3) Penanaman (4) Pemupukan, (5) Pemanenan. Dari penjelasaan di atas maka dapat disimpulkan bahwa biaya tenaga kerja usaha tani untuk $10 \mathrm{~kg}$ benih jagung sebagaimana berikut ini. 
Tabel 3. Perhitungan Biaya Tenaga Kerja

\begin{tabular}{|c|c|c|c|c|c|}
\hline No & Jenis Biaya & Unit & Satuan & Harga $(\mathbf{R p})$ & Jumlah (Rp) \\
\hline \multirow[t]{15}{*}{1} & Biaya Tenaga Kerja & & & & \\
\hline & Pra Tanam: & & & & 440.000 \\
\hline & 1. Upah Penyemprotan & 14 & Tangki & 10.000 & 140.000 \\
\hline & 2. Upah Penggemburan & 1 & Hari & 300.000 & 300.000 \\
\hline & Penanaman: & & & & 1.040 .000 \\
\hline & 1. Upah Penanaman & 6 & Orang/hari & 100.000 & 600.000 \\
\hline & 2. Upah Pemupukan & 3 & Orang/hari & 100.000 & 300.000 \\
\hline & 3. Upah Penyemprotan & 14 & Tangki & 10.000 & 140.000 \\
\hline & Pestisida Ke-2 & & & & \\
\hline & Panen : & & & & 1.600 .000 \\
\hline & 1. Upah Penebangan & 2 & Sak & 125.000 & 250.000 \\
\hline & 2. Upah Pengupasan & 90 & Koli & 10.000 & 900.000 \\
\hline & 3. Upah Pengangkutan & 90 & Koli & 4.000 & 360.000 \\
\hline & $\begin{array}{l}\text { dari kebun ke lantai } \\
\text { jemuran }\end{array}$ & & & & \\
\hline & 4. Upah Jahit & 90 & Koli & 1.000 & 90.000 \\
\hline
\end{tabular}

Sumber: Data Olahan

\section{Biaya Overhead Pabrik}

Biaya overhead pabrik adalah biaya produksi yang secara tidak langsung dapat dirasakan pada produk atau merupakan biaya produksi selain bahan baku dan tenaga kerja. Dalam usaha lainnya contoh biaya overhead pabrik adalah biaya bahan penolong, tenaga kerja tidak langsung, dan biaya produksi lainnya yang tidak dapat ditelusuri secara langsung pada produk. Adapun dalam usaha pertanian peneliti menggolongkan biaya overhead pabrik sebagaimana berikut ini.

Tabel 4. Perhitungan Biaya Overhead Pabrik

\begin{tabular}{|c|l|c|c|r|r|}
\hline No & Jenis Biaya & Unit & Satuan & Harga & \multicolumn{1}{c|}{ Jumlah } \\
\hline 1 & Biaya Overhead Pabrik & & & & $\mathbf{1 . 7 5 6 . 0 0 0}$ \\
& 1. Pestisida & 1 & Galon & 300.000 & 300.000 \\
& 2. Pupuk & 4 & & & \\
& $-\quad$ Krea & 4 & Koli & 115.000 & 460.000 \\
& - Phonska & 18 & Karung* & 120.000 & 480.000 \\
& 3. Sewa Mesin Penggiligan & 3 & Ton & 100.000 & 216.000 \\
& 4. Transportasi Ke Gudang & 300.000 \\
& 5. Sewa Lantai Jemuran (Optional) & & & & \\
\hline
\end{tabular}

Sumber: Data Olahan

\section{Laporan Harga Pokok Produksi}

Laporan harga pokok produksi merupakan akumulasi biaya bahan baku, biaya tenaga kerja dan biaya overhead pabrik, sebagaimana dijelaskan di bawah ini. 
Tabel 5: Perhitungan Biaya Produksi

\begin{tabular}{|c|l|r|c|}
\hline No & \multicolumn{1}{|c|}{ Jenis Biaya } & \multicolumn{1}{c|}{ Jumlah } & Presentase \\
\hline 1 & Biaya Bahan Baku & 800.000 & $14 \%$ \\
\hline 2 & Biaya Tenaga K & 3.080 .000 & $55 \%$ \\
\hline 3 & Biaya Overhead & 1.756 .000 & $31 \%$ \\
\hline & Total & 5.636 .000 & $100 \%$ \\
\hline
\end{tabular}

Sumber: Data Olahan

Berdasarkan data di atas kita dapat melihat bahwa total biaya produksi dalam sekali panen untuk 2 Sak Jagung (ukuran $10 \mathrm{Kg}$ ) sebesar Rp 5.636.000,- (Lima Juta Enam Ratus Tiga Puluh Enam Ribu) dengan jumlah masing-masing biaya: biaya bahan baku Rp 800.000,- (14\%) Biaya Tenaga Kerja Rp 3.080.000,- (55\%) dan Biaya Overhead Pabrik sebesar Rp 1.756.000,-. (31\%). Dari total biaya yang ada, biaya tenaga kerja merupakan biaya yang cukup tinggi, oleh karena itu alam kondisi tertentu biasanya anggota keluarga atau bahkan pemilik juga berperan sebagai tenaga kerja didalamnya untuk meminimalisir biaya (Abdullah, 2021). Dengan biaya Produksi sebesar Rp 5.636.000,- petani dapat memperoleh penghasilan sebesar Rp 10.800.000,(3.000 Kg x Rp 3.600). Keuntungan (selisih Penghasilan-Biaya) yang diperoleh petani sebesar Rp 5.164.000,- (Lima Juta Seratus Enam Puluh Empat Ribu Rupiah), atau sebesar $48 \%$ dari harga jual. Hasil ini selaras dengan penelitian yang dilakukan oleh Mardani (2017). Untuk lebih jelasnya dapat dilihat pada table di bawah ini.

Tabel 6: Perhitungan Biaya Perunit

\begin{tabular}{|l|l|r|r|r|}
\hline No & \multicolumn{1}{|c|}{ Uraian } & Jumlah & Unit Output & \multicolumn{1}{c|}{ Biaya/Kg } \\
\hline 1 & Penjualan & 10.800 .000 & $3000 \mathrm{Kg}$ & 3.600 \\
\hline 2 & Biaya Produksi & 5.636 .000 & $3000 \mathrm{Kg}$ & 1.879 \\
\hline & Keuntungan & $\mathbf{5 . 1 6 4 . 0 0 0}$ & & \\
\hline
\end{tabular}

Sumber: Data Olahan

Hasil penelitian ini dapat digeneralisir kepada semua petani dengan beberapa pengecualian diantaranya adalah:

1. Biaya transportasi dari lading ke lokasi penggilingan ( $\mathrm{Rp} 4.000)$ untuk lokasi yang dekat dengan pemukiman warga dan medannya tidak terlalu sulit. Biayanya untuk lahan berbukit dan menanjak dikenakan biaya 2x lipat sebesar Rp 8.000,- perkoli gabah (karung Ukuran $50 \mathrm{~kg}$ ) sehingga untuk unsur biaya ini dapat menjadi $2 x$ lipat

2. Harga jagung biasanya bervariasi setiap pekannya (naik atau turun) petani yang memasukkan jagungnya ke gudang pada saat harga tinggi akan mendapatkan keuntungan lebih disbanding yang memasukkan jagung pada saat harga rendah.

3. Kualitas jagung juga cukup menentukan dalam penetapan harga di gudang

4. Kuantitas (hasil) panen juga cukup bervariasi antara satu dan lainnya, misalnya ada yang lahannya subur, mendapatkan sinar matahari yang cukup dan curah hujan yang cukup juga mendapatkan hasil yang lebih dibandingkan lainnya.

5. Jenis benih menentukan kadar berat jagung setiap kg

6. Hama 


\section{KESIMPULAN}

Usaha tani merupakan usaha yang cukup menguntungkan dengan margin sebesar $48 \%$. Hal ini akan lebih baik jika para petani melakukan pencatatan secara baik yaitu dalam hal pencatatan biaya-biaya produksi yang telah dikeluarkan (Biaya Tenaga Kerja, Biaya Bahan Baku dan Biaya Overhead). Dengan adanya catatan keuangan, petani dapat memprediksikan atau merencanakan biaya-biaya apa saja yang perlu untuk diminimalisir ketika ada kondisi-kondisi yang tidak pasti misalnya naik-turunnya harga jagung atau adanya serangan hama.

Dengan adanya pencatan keuangan petani dapat mengetahui informasi keuntungan yang didapatkan dan dapat membandingkan periolehan ini dengan musimmusim sebelumnya. 


\section{DAFTAR PUSTAKA}

Abdullah, Mei. 2021. Budaya Kerja Petani Perempuan. Jurnal Neo Societal, 6(1), 104110.

Djamali, A. R. 2000. Manajemen Usaha Tani. Departemen Pendidikan Nasional, Politeknik Negeri Jember. Jurusan Manajemen Agribisnis. Jember.

Hansen \& Mowen.2009. Akuntansi Manajemen. Salemba Empat.Jakarta

Mardani \& Satriawan.2017. Analisis Usaha Tani Tanaman Pangan Jagung Di Kecamatan Juli Kabupaten Bireuen.Jurnal S. Pertanian, 1 (3) : 203 -212 (2017).

Nazir, M 2014, Metode Penelitian, Ghalia Indonesia, Bogor.

Soekartawi et al. 1995. Ilmu Usaha tani dan Penelitian Untuk Pengembangan Petani Kecil. Lembaga Penerbit Universitas Indonesia. Jakarta.

Sujarweni, Wiratna.2015. Akuntansi Biaya. Pustaka Press. Jakarta.

Tegor., Siswanto, Dwi Joko., Siagian, Mauli. (2020). Manajemen Sumber Daya Manusia. Yoyakarta. Penerbit Deepublish.

Tegor, T., Juliza, Yusmalina, \& Haqiqi, F. (2021). Penerapan Standar Akuntansi dan Kualitas Aparatur Terhadap Laporan Keuangan Pemerintah Daerah (Studi Kasus pada Dinas Pekerjaan Umum dan Penataan Ruang Kabupaten Karimun). JURNAL CAFETARIA, 2(1), 13-24. https://doi.org/10.51742/akuntansi.v2i1.276. 